\section{MP-057性差医療への取り組み〜泌尿器科の立 場から〜}

\begin{abstract}
北里研究所病院泌尿器科 ${ }^{1)}$, 北里大学医学部泌尿器科 ${ }^{21}$
大川 麻子 ${ }^{1)}$, 木村 将貴 ${ }^{12}$, 石井 淳一郎 ${ }^{13}$, 入江 啓 ${ }^{11}$, 門脇 和臣 ${ }^{1}$, 馬場 志郎 ${ }^{2)}$
\end{abstract}

【目的】生物学的な性がヒトの生理に与える影響は大きく男女 の間に差があるということがいわれている。女性の性差を踏ま えた医療を提供する場として女性外来が全国各地に開設され ている。当院でも2004 年から女性総合外来を開設したので、そ の現状と泌尿器科としてのかかわり方について報告する。【方 法】2004 年 6 9 月加性差医療のための専門外来である女性 総合外来を発足した。婦人科・精神科 - 外科 - 泌尿器科 - 内科 の各科で䛦療を行い、女性医師を外来に配置した。結果】2004 年 9 月〜 2005 年 5 月まで初診症例は 217 例。科別に見ると必 尿器科 $9.3 \%$ 、婦人科 $36.6 \%$ 、精神科 $14.1 \%$ 、外科 $35.6 \%$ 、内科 $4.4 \%$ であった。年代別に見ると 40 才代が $28.8 \%$ 、50才代 $25.4 \% 、 30$ 才代 $18.0 \%$ であった。また外来認知方法は院内紹介 が $25 \%$ 、雑誌が $13 \%$ 、インターネットが $10 \%$ であった。また 精神科以外の不眠・泌尿器科以外の夜間頻尿が高率に認めら れた。泌尿器科受診者の主訴は多いものから尿失禁、再発性膀 胱炎、排尿時痛であった。診断としては過活動膀胱、腹圧性尿 失禁、膀胱炎であった。【考察】女性総合外来においては若年 者の受診割合が多かった。また尿路感染症や血尿でも一般泌尿 器科外来に受診するのを女性が躊躇していると考える。今後も 泌尿器科受診を容易にする空口になるように努めていきたい。

\section{MP-058アミロイド多発性ニューロパチーに伴 う下部尿路障害の検討}

\section{信州大学医学部泌尿器科学}

関 聡, 井川 靖彦, 市野 みどり, 石塚 修,

三澤 和佳奈, 西澤 理

【目的】今回我々はアミロイド多発性ニューロパチーの患者にウ ロダイナミックスタデイーを行い排尿障害の検討を行ったので 報告する。【刘象】当院神経内科にてアミロイド多発性ニューロ パチーと診断され、排尿症状を持つ患者 8 名。家族性アミロイ ドーシス (FAP)が6例。原発性アミロイドーシスが1例。骨髄 腫に伴うアミロイドーシスが 1 例。【結果】排尿困難は全例に認 めた。FAPの 6 例中 3 例で尿意の消失または低下を認め、その うち2例で失禁を認めた（失禁の原因はそれぞれ排尿筋過活動 と括約筋不全)。ウロダイナミクス上、FAPの 6 例が全例で排尿 筋の収縮不全を認め、間久自己導尿が導入された。6 例中 2 例で 膀胱コンプライアンスが低下していた。失禁を認めた 2 例とも 間欠導尿の導入により失禁は軽快した。原発性アミロイドーシ スの 1 例では排尿筋過活動を認めたが、その他のパラメーター は正常であり、症状は前立腺肥大症によるものと判断した。骨䯣 腫に伴うアミロイドーシスでは排尿筋過活動と排尿時の排尿筋 压のわずかな低下を認めたが、治療なしで経過を見ている。【結 論】進行例では単なる排出障害だけでなく低コンプライアン 又膀胱や、括約笳不全、排尿筋過活動などの蓄尿障害も認められ た。FAPの症例では下部尿路障害が進行しており早期から泌尿 器科医による排尿管理が必要と考えられた。
MP-059

脳深部刺激法を施行したパーキンソン 病患者の排尿についての検討

\section{日本大学医学部泌尿器科学", 日本大学大学院医学研究 科応用システム神経科学}

杉本 周路1, 吉沢 剛" , 佐藤 克彦1, 五十嵐 匠 ${ }^{11}$, 吉田 利夫", 滝本 至得"), 小林 一太 ${ }^{22}$, 大島 秀規 ${ }^{22}$, 山本 隆充 ${ }^{2}$, 片山 容—2)

パーキンソン病に伴う排尿機能障害は、排尿筋過活動に よって惹起きれる蓄尿障害が多いと報告されている。しか しながら、詳細な問診を行うと運動機能障害によって助長 される尿意切迫感や切迫性尿失禁、また前立腺肥大を伴わ ない場合でも排出障害のある症例も存在する。またパーキ ンソン病患者のほとんどが服用している L-dopa の D2 受 容体作用優位による排尿反射促進効果、また抗コリン薬を 服用している場合の排尿筋への影響などのバイアスを考 慮して排尿障害を評価するのは非常に困難である。現在、 進行したパーキンソン病の新しい治療として注目されて いる脳深部刺激法は 2000 年に保険収載されてから、より 身近な治療となっている。今回我々は脳深部刺激法施行し たパーキンソン病患者を対象に排尿機能を評価した。対象 は、視床下核に脳深部刺激法を施行したパーキンソン病患 者 17 例（男性 11 例、女性 6 例）、平均年齢 65.2 歳。刺激 前の Hoehn-Yahr 分 類 $2.5: 1$ 例、 $3: 6$ 例、 $4: 5$ 例、 $5: 5$ 例であった。全例に排尿に関するアンケートや問診、一部 にウロダイナミクス検查を行い、排尿機能を評価した。

\section{MP-060 大動脈人工血管置換術後の脊㩆梗塞に よる神経因性膀胱}

\section{国立身体障害者リハビリテーションセンター病院}

永松 秀樹, 鈴木 常貴, 牛山 武久

【目的】大動脈人工血管置換術後の重要な合併症の一つで ある脊髄梗塞に上る神経因性膀胱について、尿流動態検 查所見と排尿方法を検討した。【対象】対象は 14 例（男 13 例、女 1 例)、発症時年齢は $32 \sim 76$ 歳であった。原因 疾患は大動脈解離 9 例、大動脈癌 5 例で、大動脈の人工 血管置換を行った部位は上行 4 例、上行〜弓部 3 例、遠 位弓部 3 例、下行〜腹部 3 例、腹部 1 例であった。全例、 術前は神経学的な異常がなく、人工血管置換術後に対麻 㽻が出現した。麻痺レベルは Th3〜L1（上部胸髄 5 例、 下部胸佮道 8 例、腰骮道 1 例) で、ASIA A3 例、B4 例、C5 例、D2 例であった。【結果]尿流動態検查を 13 例に行っ た。蓄尿期に排尿筋過活動 7 例、膀胱コンプライアンス 低下 7 例、括約筋不全を 3 例に認めた。排尿期は全例が 排尿筋低活動あるいは無収縮であった。尿意は ASIA D の 1 例では正常であったが、 4 例で低下、7例で消失し、 1 例は代償尿意のみみられた。リハビリテーション終了 時の排尿方法は自己導尿 12 例、尿道カテーテル留置 2 例で、自排尿可能となった症例はなかった。【結論】大 動脈人工血管置換術後の春葡梗塞による神経因性膀胱は 機能障害が比較的強く、自排尿となった例はなかった。 